\title{
Analysis of Syngas Results of the Maindepth Coal Gasification Process with Gasification Downraft Methods
}

\author{
Erlinawati Erlinawati ${ }^{1, *}$ Aida Syarif ${ }^{1}$ Arizal Azwan $^{1}$ Tahdid Tahdid $^{1}$ \\ ${ }^{1}$ Energy Engineering Applied Undergraduate, Sriwijaya State Polytechnic \\ "Corresponding author. Email: erlinawatiakil @yahoo.co.id
}

\begin{abstract}
According to the Geological Agency (2015), Indonesia's resources total are 106.845 billion tons and coal reserves are 32.263 billion tons. Behind the reasons for choosing coal as an energy source, there are still some disadvantages of using coal directly. One of them is the coal contains a lot of pollutant that are harmful to the environment. Coal releases gases $\left(\mathrm{CO}_{2}, \mathrm{~N}_{2} \mathrm{O}\right.$, NOx, SOx and $\left.\mathrm{Hg}\right)$ that caused global warming and pollution. The process of solid convert to gas is called Gasification is. In contrast to combustion, the process of is a breaking of the carbon chain into the form of other elements or chemical compounds. In this study, the gasification process was carried out using the downdraft method. Gasification of coal will be produce producer gas in the form of synthetic gas (syngas) with the main components consisting of $\mathrm{CO}$, $\mathrm{H}_{2}, \mathrm{CO} 2$ and $\mathrm{N}_{2}$ and low in pollutants. This study aims to determine the effect of the type of coal seam on the syngas produced, the calorific value of the syngas, and the effect of the air flow rate.
\end{abstract}

Keywords: Gas Fuel, Downdraft Gasification, Coal, Syngas Results

\section{INTRODUCTION}

Indonesia has potential resources and coal reserves which are spread mostly on the islands of Kalimantan and Sumatra, and a small portion of the rest is spread across several locations on the islands of Java, Sulawesi and Papua. According to the Geological Agency (2015), Indonesia's total resources are 106.845 billion tons and coal reserves are 32.263 billion tons. The quality of Indonesian coal resources is quite varied in terms of caloric parameters, ash content, sulfur content, total moisture, and other parameters (BAPPENAS, 2019). Behind the reasons for choosing coal as an energy source, there are still some disadvantages of using coal directly. One of them is that coal contains a lot of pollutants that are harmful to the environment. Coal releases gases $(\mathrm{CO} 2, \mathrm{~N} 2 \mathrm{O}, \mathrm{NOx}$, $\mathrm{SOx}$ and $\mathrm{Hg}$ ) that cause global warming and pollution.

The development of coal conversion in Indonesia is basically an inseparable part of encouraging the increase in added value of coal that must be carried out by coal entrepreneurs as stipulated in Government Regulation Number 23 of 2010 articles 94, 95, and 96 and national energy policies based on Government Regulations of the Republic of Indonesia. Number 79 of 2014 concerning energy diversification (article 18 paragraph 2 point b) states that one of the energy diversification is through increasing the use of low quality coal for gasified coal.

Gasification is a process of converting solid fuel into gas. In contrast to combustion, the gasification process is the process of breaking the carbon chain into the form of other elements or chemical compounds. The gasification process requires little oxygen and water vapor is often used for the combustion process [2]). By converting coal into gas, unwanted materials contained in coal such as sulfur compounds, carbon dioxide $(\mathrm{CO} 2)$, and ash can be removed from the gas using certain methods so that clean gas can be produced. Coal gasification will produce producer gas in the form of synthetic gas (syngas) with the main components consisting of carbon monoxide (CO), hydrogen (H2), carbon dioxide $(\mathrm{CO} 2)$ and nitrogen $(\mathrm{N} 2)$ which are low in pollutants. So that energy experts have focused on developing coal gasification to meet future energy consumption. (Sutrisna, I.P., 2007). The research that I will take focuses on the syngas gasification results from the mine depth coal downdraft method, types of coal seams (A1, A2, B and C), and the effect of air flow rate. 


\subsection{Characteristics of Coal}

Each type of coal has a different composition. Factors that cause this include the initial decomposition of coal origin through diagenetic processes and coalification [3]. The heterogeneity of coal properties is estimated in various relationships of its constituent components, such as the relationship between hydrogen and carbon content, oxygen and carbon content, and volatile content and calorific value. The quality of each coal deposit is determined by temperature and pressure and the length of time it forms, which is referred to as 'organic maturity'. Proximate coal content testing is needed to determine the character and composition of coal. Coal proximate analysis can be seen in Table 1:

Table 1. Proximate Analisys from each coal sample

\begin{tabular}{|c|c|c|c|c|c|}
\hline \multirow{2}{*}{\multicolumn{2}{|c|}{ Type of Analisys }} & \multicolumn{4}{|c|}{ Type of Coal Seam } \\
\hline & & \multirow{2}{*}{$\begin{array}{c}\text { Tipe } \\
\text { A1 }\end{array}$} & \multirow{2}{*}{$\begin{array}{c}\text { Tipe } \\
\text { A2 }\end{array}$} & \multirow{2}{*}{$\begin{array}{c}\text { Tipe } \\
\text { B } \\
2,09\end{array}$} & \multirow{2}{*}{$\begin{array}{c}\text { Tipe C } \\
2,10\end{array}$} \\
\hline \multirow{4}{*}{ Proximate } & $\begin{array}{l}\mathrm{TM} \\
(\%)\end{array}$ & & & & \\
\hline & $\begin{array}{l}\mathrm{VM} \\
(\%)\end{array}$ & $\begin{array}{c}42,9 \\
6\end{array}$ & $\begin{array}{c}42,4 \\
7\end{array}$ & 35,20 & 34,99 \\
\hline & $\begin{array}{l}\text { Ash } \\
(\%)\end{array}$ & 4,77 & 4,78 & 8,57 & 8,58 \\
\hline & $\begin{array}{l}\text { FC } \\
(\%)\end{array}$ & $\begin{array}{c}45,7 \\
0\end{array}$ & $\begin{array}{c}46,1 \\
2\end{array}$ & 54,14 & 54,34 \\
\hline
\end{tabular}

Table 2. Caloric Value of Coal Sample

\begin{tabular}{c|c}
\hline Type of Coal Seam & $\begin{array}{c}\text { Caloric Value } \\
\text { (Cal/gr) }\end{array}$ \\
\hline Tipe A1 & 3481,6153 \\
\hline Tipe A2 & 4541,4801 \\
\hline Tipe B & 4651,2393 \\
\hline Tipe C & 5217,9419 \\
\hline
\end{tabular}

\subsection{Coal Gasification}

The thermochemical conversion of coal can be in the form of pyrolysis, gasification and combustion (combustion). The difference in the type of conversion lies in the amount of air (oxygen) consumed and the output during the conversion process. Gasification technology is a form of increasing the energy contained in coal through a conversion from a solid phase to a gas phase using a thermal degradation process of organic materials at high temperatures in incomplete combustion using limited air (20\%-40\% air). stoichiometry) [4]
The fuel used for the gasification process uses materials containing hydrocarbons such as coal and biomass. The entire gasification process occurs in the gasifier. In this gasifier, a heating process occurs to a certain reaction temperature and then the fuel goes through a combustion process by reacting with oxygen to produce combustible gas and other combustion products. Water vapor and carbon dioxide from combustion are reduced to flammable gases, namely carbon monoxide (CO), hydrogen (H2) and methane (CH4) which can then be used as power plants or stoves.

\subsection{Downdraft Gasification}

The development of gasification technology makes the process of research and development of gasifiers continue to be carried out. The development was carried out with various considerations, including reducing the tar and sulfur content in the syngas product. The downdraft gasifier is a reactor with the direction of the flow of air and raw materials both going down. Syngas flows down and gasifier. [5]. Stated that the reason for choosing the downdraft type gasifier was due to 4 things, namely:

1. Lower manufacturing costs,

2. The gas produced is hotter than the updraft system

3. Easier to proceed to the combustion process

4. Lower tar than updraft. This is because the tar which is the result of pyrolysis is carried along with the gas and then enters the combustion area (combustion) and then gasification which has a higher temperature. In this area of gasification and combustion, tar will then decompose.
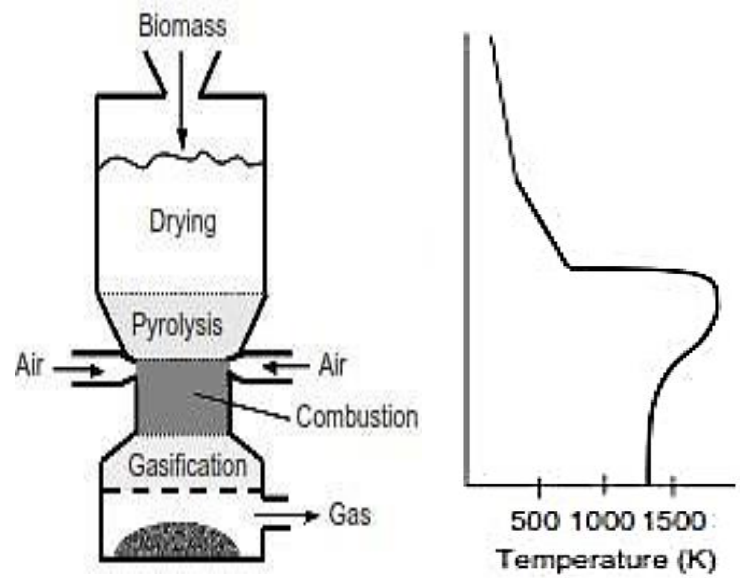

Figure 1. Scheme of Downdraft [6]

\subsection{Effect of Coal Rank on Syngas Products}

The type of coal is very important to the desired syngas yield. Riza Abrar (2017) states that the conversion of $\mathrm{H} 2$ gas resulting from gasification is mostly produced 
by lignite type coal compared to subbituminous and anthracite coal types. However, for the type of coal that produces $\mathrm{CO}$ conversion, anthracite has the highest maximum $\mathrm{CO}$ conversion rate, followed by bituminous and lignite. This condition is based on the carbon content of the type of coal. Based on these levels, gasification is divided into 3 products, namely: Low-Btu gas (150-300 Btu/scf), Mediu-Btu gas (300-550 Btu/scf) and High-Btu gas (980-1080 Btu/scf). The product composition is shown in Table 3:

Table 3. Classification of Gasification Product

\begin{tabular}{|l|l|}
\hline \multicolumn{1}{|c|}{ Product } & \multicolumn{1}{|c|}{ Composition } \\
\hline $\begin{array}{l}\text { Low-Btu gas (150- } \\
\text { 300 Btu/scf), }\end{array}$ & $\begin{array}{l}50 \% \text { nitrogen smalles } \\
\text { component } \mathrm{H}_{2} \text { dan } \mathrm{CO}, \mathrm{CO}_{2} \text { dan } \\
\text { sedikit gas metana }\end{array}$ \\
\hline $\begin{array}{l}\text { Medium-Btu gas } \\
\text { (300-550 Btu/scf) }\end{array}$ & $\begin{array}{l}\text { Dominantly CO dan } \mathrm{H}_{2} \text {, and } \\
\text { small unburnerd gas, smallest } \\
\text { methane gas }\end{array}$ \\
\hline $\begin{array}{l}\text { High-Btu gas (980- } \\
1080 \mathrm{Btu} / \mathrm{scf}) .\end{array}$ & Pure all methane gas \\
\hline
\end{tabular}

\section{RESEARCH METHODS}

\subsection{Tools and Material}

The tools and materials used in this research are a set of downdraft type coal gasification equipment, bomb calorimeter (Parr 6200), electric sieve shaker (Ziaulhaq Solution), furnace (Naberthem), gas analyzer, PTBA coal, and air.

\subsection{Flow Diagram}

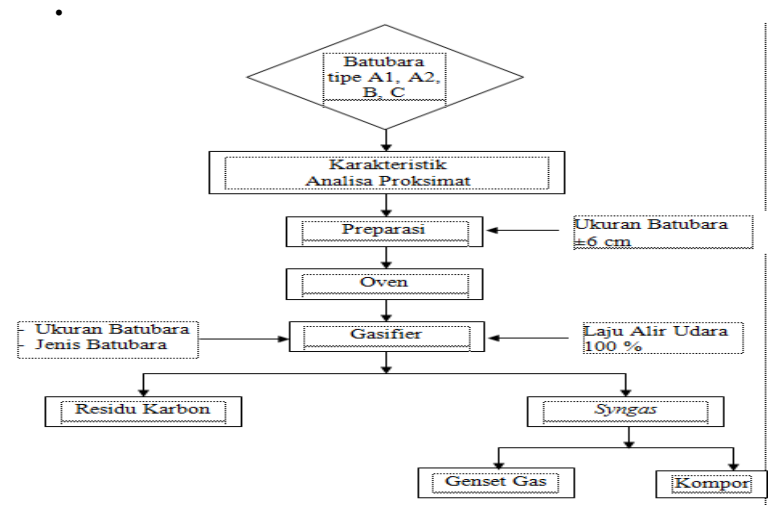

Figure 2. Flow diagram Of Gasification Process

\section{RESULT AND DISCUSSION}

\subsection{The Effect of Coal Layer Types on the Increase in Temperature and Flash Time}

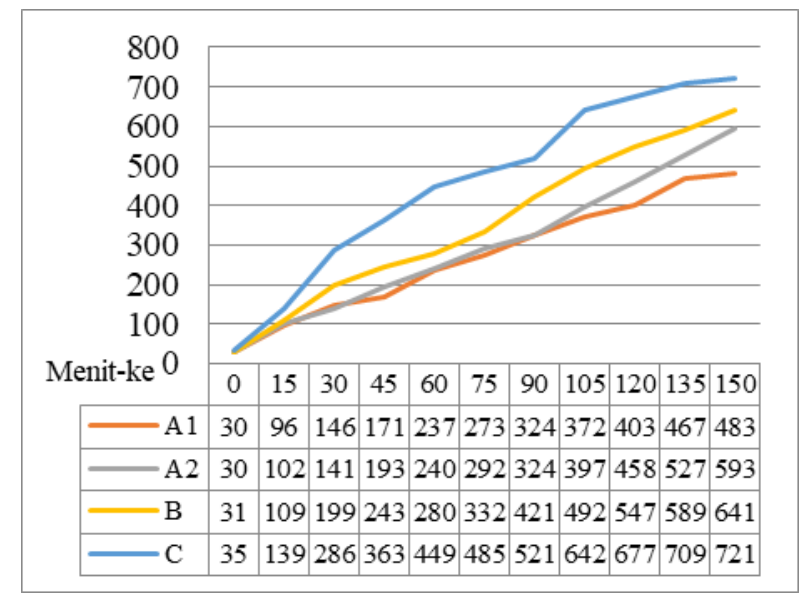

Figure 3. Graph of the relationship between coal types and temperature rise

In Figure 3. it is shown that the highest temperature is type $\mathrm{C}$ coal seam, this is because type $\mathrm{C}$ coal has the highest heating value, which is 5217.9419 $\mathrm{Cal} / \mathrm{gr}$, and the water content in type $\mathrm{C}$ coal is low enough so that the temperature achieved higher than coal with a calorific value below $5217.9419 \mathrm{Cal} / \mathrm{gr}$.

Pratama (2019) stated that the lower the water content of the raw materials and the higher the carbon value of the raw materials, the longer the flame of the syngas produced. Based on the research that has been done, the effect of the type of coal seam on the length of the flame is shown in Figure 4. there is an increase in the length of the flame from 2 minutes to 13 minutes. The shortest flame time is in type A1 coal with a heating value of $3481.6153 \mathrm{Cal} / \mathrm{gr}$ and the flame time is 2 minutes. While the longest flame time is in type $\mathrm{C}$ coal with a calorific value of $5217.9419 \mathrm{Cal} / \mathrm{gr}$ and a long flame time is 13 minutes.

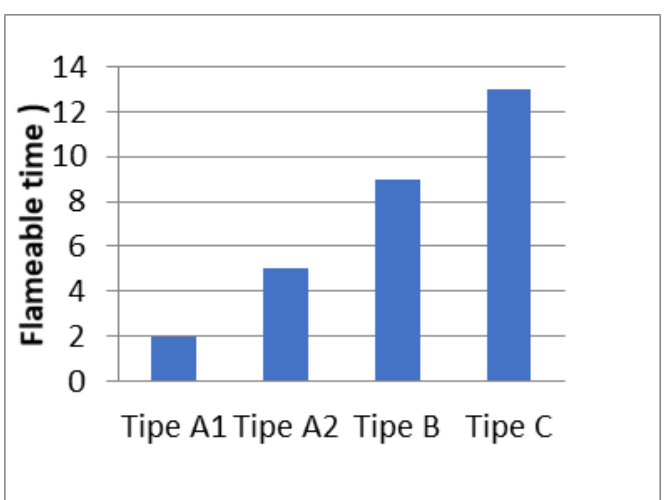

Figure. 4. Graph Relationship Between Type Of coal With Flameable 


\subsection{The Effect of Coal Types on Syngas Composition}

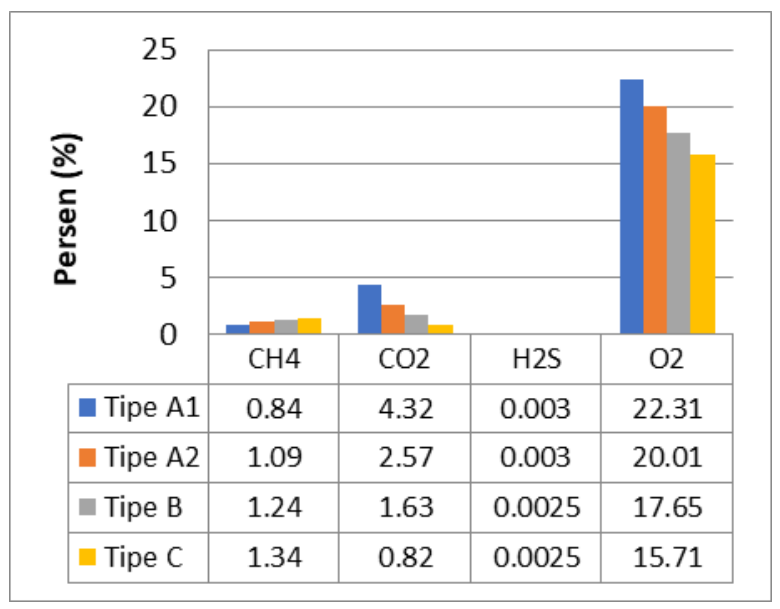

Figure 5. Graph Of SyngGas Composition

Based on Figure 5, it can be seen that the high calorific value of the coal used can indicate the amount of carbon content in the coal. [7] in his research shows that the value of the $\mathrm{CH} 4$ composition depends on the ultimate and proximate composition of the type of fuel used. Based on these factors, the higher the carbon value contained in a fuel, the more $\mathrm{CH} 4$ compounds will be formed. Meanwhile, the smaller the $\mathrm{H} 2$ value of the raw material causes the low $\mathrm{H} 2$ contained in the raw material.

The high composition of oxygen in syngas is caused by the large diameter of the circle of the air intake pipe used, causing a lot of air to enter the combustion chamber.

\subsection{The Effect of Coal Types on Heat Heating Value Syngas}

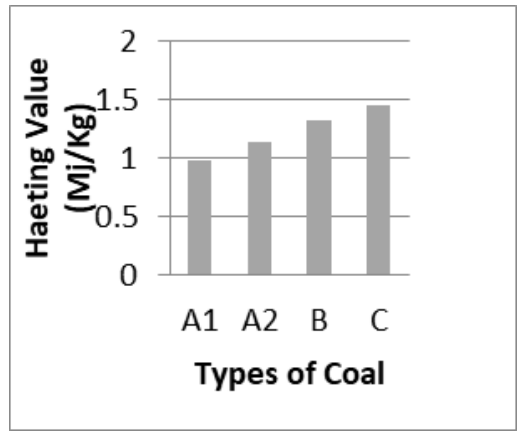

Figure 5. Graph Relationship Between Type Of coal With Heating Value

Heating Value or calorific value is an important indicator in all fuels. Heating value is an indicator that indicates how much heat the fuel can produce. The heating value of syngas affects the type of coal used. In Figure 5. based on the calorific value analysis data that has been carried out, it can be seen that the type of coal affects the heating value of the resulting syngas. This is because the lower the calorific value of coal causes the lower composition of the gas capable of combustion.

The heating value is influenced by the number of combustible gas compositions in a fuel, the combustible gas is $\mathrm{CH} 4$. With the higher value of $\mathrm{CH} 4$ composition, the heat of formation of gas capable of burning in the reduction chamber is also high. This is directly proportional to the higher the heating value, the higher the required heat requirement. [8] states that the higher the energy content of the fuel, the higher the syngas gasification results because the energy converted is also high.

\section{CONCLUSION}

From the results of observations and tests that have been carried out, the following conclusions are obtained:

1. The fastest increase in temperature is shown by Type $\mathrm{C}$ coal with a heating value of 5217.9419 $\mathrm{Cal} / \mathrm{gr}$ with a flame time of 13 minutes. The increase in temperature and duration of flame is caused by the low value of moisture contained in the coal.

2. The type of coal seam is one of the factors that affect the syngas produced. This factor is caused by the composition in the coal that affects the high and low value of $\mathrm{CH} 4$ gas that will be formed. Type $\mathrm{C}$ coal seam is a type of seam

\section{AUTHORS' CONTRIBUTIONS}

In this writing, the research team commits that the author respondents are ERLINAWATI.

\section{ACKNOWLEDGMENTS}

We would like to thank the Sriwijaya State Polytechnic for funding this research.

\section{REFERENCES}

[1] BAPPENAS. 2019. Final Report of the Study on Achievement of the Coal DMO Target of $60 \%$ of National Production in 2019. Jakarta: Directorate of Energy, Mineral and Mining Resources BAPPENAS

[2] Higman,C. dan Burgt, M.2003. Gasification. New York: Elsevier Science.

[3]. Speight, James G. 2005. "Handbook of Coal Analysis. Vol 166”. Canada: Wiley Interscience 
[4] Trifiananto, Muhammad. 2015. Characterization of Updraft Coal Gasification with Variation of Equivalence Ratio. Surabaya: Sepuluh November Institute of Technology

[5] Putri, G., A. 2009. Effect of Temperature Variation of Gasifying Agent II Gasification Media on Color and Flame Temperature in Downdraft Reactor Gasification with Corn Cobs as Raw Material. Final Report. Industrial Technology. Mechanical Engineering. Sepuluh November Institute of Technology. Surabaya

[6] Hougen, O.A., Chilton, T.H., Drew, T.B., Keyes, D.B., Watson, K.M. 1960. Chemicals Process Principles. John Wiley and Sons.New York

[7] Iswanto, Toto, dkk. 2015. "Synthetic Gas (Syngas) Plant Design from Low Quality Coal Gasification as Gas Supply PT. Fertilizer Sriwidjaja" in ITS Engineering Journal Vol. 4, No. 2 (P. 145). Surabaya: Sepuluh November Institute of Technology

[8] Riza, Abrar., dkk.2017. Effect of Carbon Content on the Gasification Process. in SINERGI Journal Vol. 21, No. 1(1-8). Bandung: Bandung Institute of Technology
[9] Satriya, Aditya. 2019. The Effect of Variations in Palm Shell Size on the Gasification Process on the Performance of the Updraft Type Gasifier in the JTM Journal. Vol. 07 No. 02, P 49-54 Surabaya: Surabaya University

[10] Suhendri, Endang. 2016. "Effect of Flow Rate and Size of Tobacco Leaf Stem Waste on Syngas Using an Updraft Gasification Reactor" in the Journal of Engineering Vol.12 No.1 (P 65-74). Banten : Sultan Ageng Tirtayasa University

[11] Sutrisna, I.P, Rahardjo, B.S. 2007. Basic Design of Floating Bed Circulating Coal Gasifier to Generate $1 \mathrm{Mw}$ of Electricity in the Indonesian Journal of Science and Technology Vol. 9 No 2 (P 53-54). Jakarta: BPP Teknologi

[12] Syarif, Aida, dkk. 2020. Effect of Variation in Air Flow Rate and Filter on Gasification Process with Downdraft System in the Journal of Kinetics Vol.11 No. 01 (36-44). Palembang: Politeknik Negeri Sriwijaya

[ 13] Winarno, Agus, dkk. 2016. Preliminary Study of the Effect of Low-Rank Coal Characteristics of the Kutai Basin on Coal Gasification in the Promine Journal Vol. 4 (2), page 1 - 12. Samarinda: Mulawarman University 